\title{
Papillary, Follicular, Hurthle Cell, Poorly Differentiated, and Anaplastic Thyroid Carcinoma pT3a TNM Finding v8
}

National Cancer Institute

\section{Source}

National Cancer Institute. Papillary, Follicular, Hurthle Cell, Poorly Differentiated, and Anaplastic Thyroid Carcinoma pT3a TNM Finding v8. NCI Thesaurus. Code C140920.

Tumor measuring more than $4 \mathrm{~cm}$ in greatest dimension limited to the thyroid. (from AJCC 8th Ed.) 